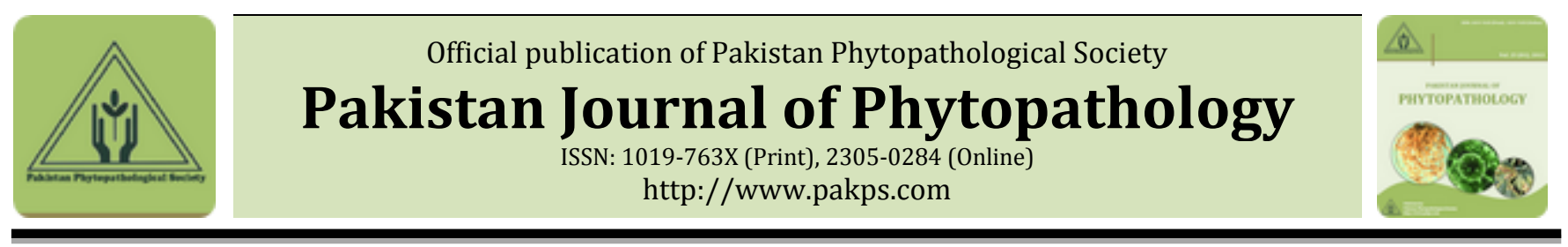

\title{
SCREENING OF SUGARCANE CULTIVARS AGAINST COLLETOTRICHUM FALCATUM CAUSING RED ROT DISEASE AND ITS CONTROL WITH DIFFERENT FUNGICIDES UNDER LABORATORY CONDITIONS
}

\author{
Muhammad U. Ghazanfar*, Waqas Raza, Sharjeel K. Gondal \\ Department of Plant Pathology, University College of Agriculture, University of Sargodha, 40100 Sargodha, Pakistan.
}

\section{A B S T R A C T}

Ten sugarcane (Saccharum officinarum L.) cultivars were screened against red rot disease caused by Colletotrichum falcatum under laboratory conditions by artificial inoculation technique. These cultivars were graded under various levels of resistance as well as susceptibility using a standard disease rating scale. Two cultivars i.e. NSG-59 and SPF244 showed resistant reaction to red rot of sugarcane. Three cultivars i.e. CPF-246, CPF-247 and BF-138 showed moderately resistant (MR) reaction against red rot. Remaining five cultivars showed moderate, susceptible to highly susceptible reaction. The results of in vitro evaluation of seven fungicides at four concentrations (10 ppm, $15 \mathrm{ppm}, 20$ ppm and $25 \mathrm{ppm}$ ) showed that all tested fungicides with all concentrations significantly inhibited the mycelial growth of the pathogen as compared with control. However, the inhibition percentage was increased by increasing the concentrations of tested fungicides. Among fungicides Tilt proved the most effective fungicide by inhibiting linear mycelial growth at all concentrations against of $C$. falcatum followed Nativo while Metaxyl\&Mencozeb was the least effective in terms of retarding fungal growth. The findings of the present study suggested that resistant cultivars may be utilized as a source of resistance and may be more useful as donors in breeding programme aimed at red rot disease resistance and the growth of the pathogen is effected by different concentrations of fungicides may play an important role to manage this disease.

Keywords: Sugarcane, Colletotrichum falcatum, red rot, management, fungicides

\section{INTRODUCTION}

Sugarcane (Saccharum officinarum L.) is an important agro industrial and leading crop by production in the world (Kinkema et al., 2014). Pakistan ranks 4th in cane acreage and 5th in sugar production globally (Shahina et al., 2007). The main limitations in the ideal sugarcane production in Pakistan comprise abiotic and biotic stresses which are responsible for its low yield (Kumar et al., 2014). Sugarcane crop prone to almost 100 different diseases caused by fungi, bacteria, nematodes, among them, red rot of sugarcane is the most destructive disease of cane which are caused by fungus, called as Cancer of sugarcane. (Khan et al., 2011; Bharti et al., 2012). In the recent years 2003 to 2006, it caused maximum losses in cane industry. (Hussnain and

* Corresponding Author:

Email: usmanghazanfar1972@gmail.com

(C) 2017 Pak. J. Phytopathol. All rights reserved.
Afghan, 2006). Therefore, an extensive range of cane cultivars have become prone to red rot (Viswanathan et al., 2003).

For the first time, it has been reported in Indonesia in 1893 which was later on named as red rot of sugarcane (Butler,1906). In Pakistan, this pathogen first reported in 1986 by Ahmed et al., 1986. The major reason of common of red rot disease in Pakistan is due to cultivation of susceptible Sugarcane varieties that difficult to incorporate the new sugarcane cultivars with developed agronomic features and resistance to biotic and abiotic stresses (Zamir et al., 2012).

Red rot of sugarcane may infect developed stems of cane, leaf mid ribs which results in considerable damages in sugar quality (Rao et al., 2008). The pathogen is setts-borne and inactive mycelia existing in the bud scales are responsible for post-germination 
and contaminate the freshly developing shoots of cane (Viswanathan and Rao, 2011).

Managing of red rot of sugarcane has been considered as thought-infuriating part of work for the scientists. The Pathogenicity of the pathogen depends upon environmental factors as well as its genotypes and existence of virulent pathogen. Furthermost the suggested management tools are aimed at agronomical practices to decrease the spread of pathogen in the field (Viswanathan and Rao, 2011). Integrated Disease Management should be adopted in the field of sugarcane because single method would not be useful to reduce the losses with respect to diversity in the types of pathogen (Agnihotri, 1996). Among all management strategies Fungicides show a vibrant role in disease management since they control many other plant diseases adequately. Several Fungicides used for the management of the disease but limited success was attained in field conditions (Singh and Singh, 1989).Keeping in the mind regarding efficacy of fungicides in the field the alternative way to combat with the disease is screening of sugarcane varieties for identification of commercially superior (high sugar and high yielding) varieties with resistance/tolerance against pathogen of red rot of sugarcane (Gupta et al., 1982; Viswanathan et al., 1996; Viswanathan and Samiyappan, 2002; Malathi et al., 2008). The objectives behind this work were (i) Screening of sugarcane varieties against $C$. falcatum causing red rot of sugarcane (ii) In vitro evaluation of different fungicide at different concentration against red rot through poisoned food technique

\section{MATERIALS AND METHODS}

The present study was conducted in the Laboratory of Plant Pathology, University College of Agriculture, University of Sargodha (Sargodha, Pakistan) during 2014-2015, in order to evaluate the efficacy of different fungicides against $C$. falcatum causal agent of red rot of sugarcane. Different varieties of sugarcane were also screened against red rot of sugarcane under field conditions at experimental area of University College of Table 1 . Reaction to variety on $0-9$ scale:

\begin{tabular}{cl}
\hline $0.0-02$ & Resistant (R) \\
\hline $2.1-4.0$ & Moderately resistant (MR) \\
\hline $4.1-6.0$ & Moderately susceptible (MS) \\
\hline $6.1-8.0$ & Susceptible (S) \\
\hline 8.1 and above & Highly Susceptible (HS) \\
\hline
\end{tabular}

Agriculture, Sargodha. Sugarcane stalks were cut longitudinally with sterilized knife and part of stalk showing red color, typical symptoms of disease were cut into small pieces along with growing margins of about $1.5-2 \mathrm{~cm}$. Surface sterilized with $0.1 \%$ bleach for approximately 2 minutes then washed three times with distilled water and placed on petri plates having potato dextrose agar (PDA). Petri plates were incubated at 28 $\pm 1^{\circ} \mathrm{C}$ for one week to check the sporulation for further studies. Single spore technique used for obtaining pure culture by incubating at $28^{\circ} \mathrm{C}$ for one week and observed it daily to get rid of contamination. (Hansen, 1926; Choi et al., 1999).

Pathogenicity Test: Sugarcane stalks were cut into small pieces in such a way that each piece has 3-4 internodes of sugarcane. These small pieces were washed with water for removal of contamination i.e. dust etc. on their surface and then apply $1 \%$ sodium hypochlorite for 2-3 minutes followed by washing with distilled water and then subjected to natural air drying. After drying, these pieces were split into two parts longitudinally with help of knife. Single bit of fungus was placed in center of each piece, with help of inoculating needle from petri plates having fungal colony, covered all sugarcane pieces so that moisture may development of symptoms (Figure 1). After 5 days of inoculation, pieces were again cut longitudinally and watched for symptoms expression of disease. Re-isolations were made from artificially infected sugarcane pieces and compared with pure cultures to confirm pathogenicity of pathogen. Ten sugarcane varieties were screened against red rot disease of sugarcane in the field of Plant Pathology, University College of Agriculture, Sargodha during 2014-2015. Disease was rated by disease rating scale used by Srinivasan and Bhat, 1987 (Table 1). Sugarcane varieties used for screening were jhnag-59, CO-1148, CPF 247.CPF 248, CPF 246, NSG-59, S-2002-US-162, BF-138, SPF-244 and HS-12. not loss and placed in incubator at $28^{\circ} \mathrm{C}$ for the

Varietal screening against red rot of sugarcane: 


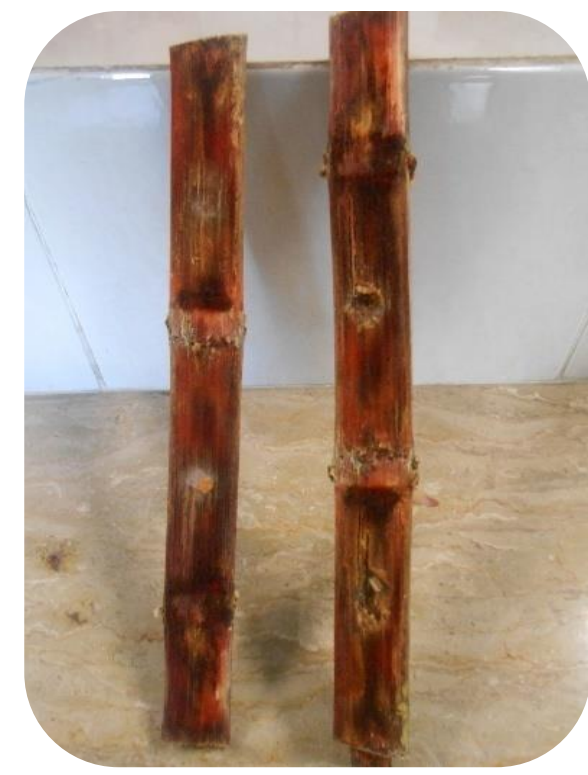

a

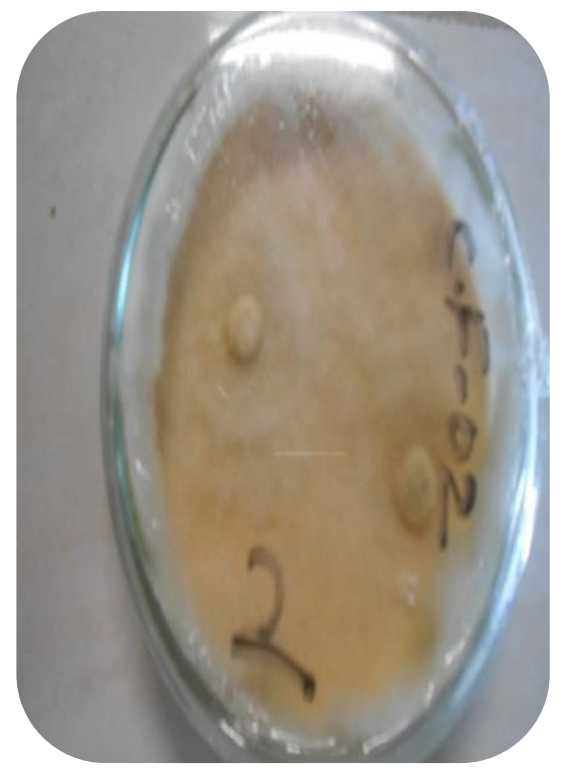

b

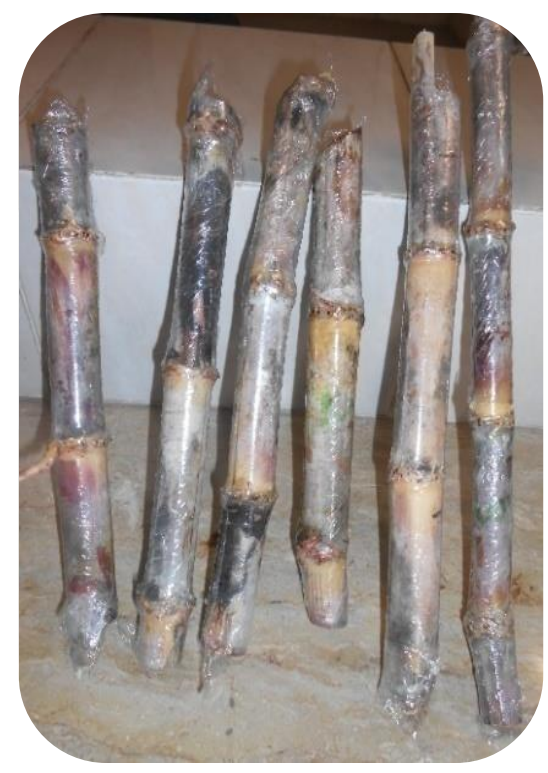

C

Figure 1: $a=$ Symptoms after 5 days of inoculation $b=$ Fungus colony after re-isolation $c=$ Wrapped canes

Evaluation of fungicides: Seven different fungicides at different tested concentrations (Table 2) i.e. 10, 15, 20 \& $25 \mathrm{ppm}$ and each replicated thrice through use of poisoned food technique (Sharvelle, 1961) against $C$. falcatum causing red rot. Fungicides were obtained from Table 2. Fungicides description.

\begin{tabular}{clll}
\hline Sr. No. & Trade Name & Active ingredient & Manufacturers \\
\hline 1 & CabrioTop 600WDG & Metriam+Pyraclostrobin & Arysta Life Sciences \\
2 & Dew 250\%EC & Difenconazole & Four Brothers \\
3 & Secex & Metaxyl & United Distribution \\
4 & Metaxyl+MencozebWP & Metaxyl+Mencozeb & Bayer Crop Sciences \\
5 & Tilt@250 EC & Propeconazole & Syngenta \\
6 & Rally®40WSP & Myclobutanil & Dow AgroSciences \\
7 & Nativo®WG 75 & Trifloxystrobin+Tebuconazole & Bayer Crop Sciences \\
\hline
\end{tabular}

Preparation of fungicides concentration: Potato dextrose agar was used and requisite concentration of each fungicide was added to get a required concentration. The fungicides were carefully mixed by stirring and about $15 \mathrm{ml}$ poisoned medium was poured to each of the $90 \mathrm{~mm}$ petri dishes and allowed for solidification. The actively growing margins of the seven days old culture of the pathogen was carefully cut using cork borer and transferred aseptically to the center of each petri dish. Suitable control was maintained on PDA having no fungicide. The petri plates were incubated at $28 \pm 1^{\circ} \mathrm{C}$ for one week and the colony diameter was recorded after seven days growth of pathogen according to the description (Benicio et al., 2003).

\section{STATISTICAL ANALYSIS}

Statistical analysis was performed using $\mathrm{R}$ Software. Three factor factorial analysis were used for the registered pesticide dealers located in the market of Faisalabad (Punjab, Pakistan).

Whereas percent inhibition calculated by Percent inhibition $=\mathrm{X}-\mathrm{Y} / \mathrm{X} \times 100$

Where, $\mathrm{X}=$ Colony diameter in check, $\mathrm{Y}=$ Colony diameter. evaluation of synthetic fungicides results. Fisher's LSD test was used to compare treatment means (Fisher, 1948). RESULTS

Pathogenicity Test: After 5 days of inoculation, sugarcane pieces were split longitudinally and observed for symptoms expression of disease. Red color symptoms were seen as reddening of vascular area and also bad odour (Figure 1).

Screening: After two months of inoculation, inoculated canes were split longitudinally and disease incidence was noticed on basis of lesions breadth, spots color i.e. white or black, number of nodes transgressed by fungal development and condition of tops. Linear spread of disease in stalk was measured in centimeters in all varieties. Characteristic symptoms of red rot disease i.e. yellowing, drying of leaves, red discoloration throughout the length of the stalk and production of white spots within 
the internal portion of cane appeared on some inoculated plants.

Among ten varieties (Table 3), two varieties such as NSG-59 and SPF-244 scored 2 on disease rating scale and proved to be resistant against the attack of red rot disease. Three varieties such as BF-138, CPF 246and CPF 247 score 4, 3 and 4 respectively on disease rating scale. These three varieties showed moderately resistant response to attack of pathogen. CPF 248 showed moderately susceptible response towards red rot disease, Whereas, all other varieties have susceptible and highly susceptible response on disease attack. Long lasting and more reliable method for controlling disease is to introduce such varieties that are resistant to disease by breeding programs (Sengar et al., 2009).

Table 3: Response of varieties towards red rot of sugarcane

\begin{tabular}{llll}
\hline Sr No. & Variety & Score on 0-9 scale & Response \\
\hline 1 & CPF 247 & 4 & Moderately resistant \\
2 & CPF 248 & 5 & Moderately susceptible \\
3 & CPF 246 & 3 & Moderately resistant \\
4 & Jhnag-59 & 7 & Susceptible \\
5 & NSG-59 & 2 & Resistant \\
6 & SPF-244 & 2 & Resistant \\
7 & HS-12 & 9 & Highly Susceptible \\
8 & S-2002-US-162 & 7 & Susceptible \\
9 & BF-138 & 4 & Moderately resistant \\
10 & CO-1148(Check) & 9 & Highly Susceptible \\
\hline
\end{tabular}

Evaluation of synthetic fungicides: All tested fungicides with all concentrations significantly $(P \leq 0.01)$ inhibited the mycelial growth of the pathogen when compared with control (Table 4).

The fungicides evaluated after seven days of colony growth by taken inhibition percentage of all tested concentrations. Data regarding inhibition percentage of fungus (Table 4, Figure 2) revealed that Tilt was the most effective fungicide inhibited mycelial growth at all concentrations (57.85\% to $81.67 \%$ ) against C. Falcatum followed by Nativo (50.37\% to $75.18 \%$ ), Secex (45.18\% to $71.12 \%)$, Dew (39.63\% to $64.63 \%$ ), Cabrio top ( $25.74 \%$ to $42.59 \%$ ), Rally ( $10.67 \%$ to $53.7 \%$ ) and least inhibition was recorded with Metaxyl and Mancozeb
$(7.78 \%$ to $33.7 \%)$ when compared with control. The mycelial growth of pathogen was significantly different within the 4 concentrations of each fungicide. Similar results were found Bharti et al., (2014) by reporting Tilt effectiveness against $C$. falcatum. Metaxyl and Mencozeb and Cabrio Top don't show god effects on fungal mycelium. These both fungicides have very narrow effects on $C$. falcatum growth. Dew and Rally have also not significant effects on fungal growth at lower concentrations but inhabit fungal development at higher concentrations. Dew showed good effects on $25 \mathrm{ppm}$ concentration as compare to Rally. Cabrio Top failed to inhabit fungal growth at highest concentration used (Figure 3).

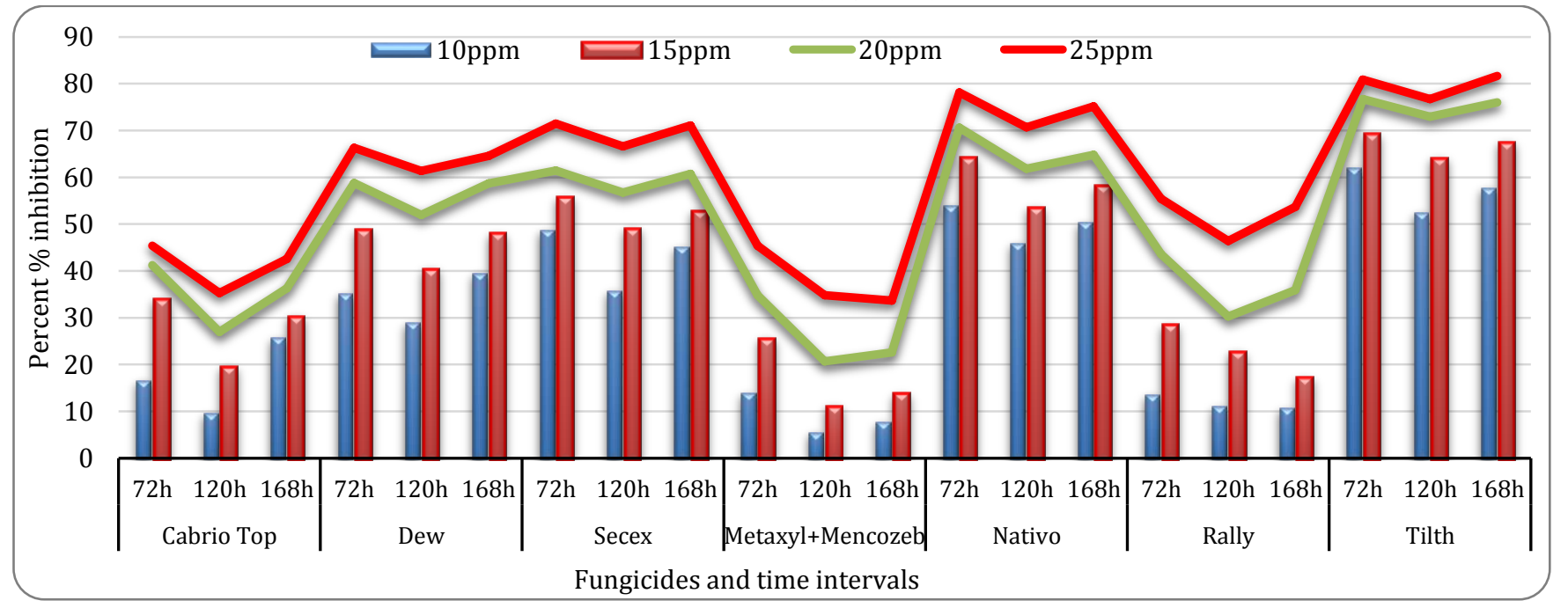

Figure 2. Growth inhibition percentage (\%) of C. falcatum against different concentrations of fungicides, applied as food poison technique 


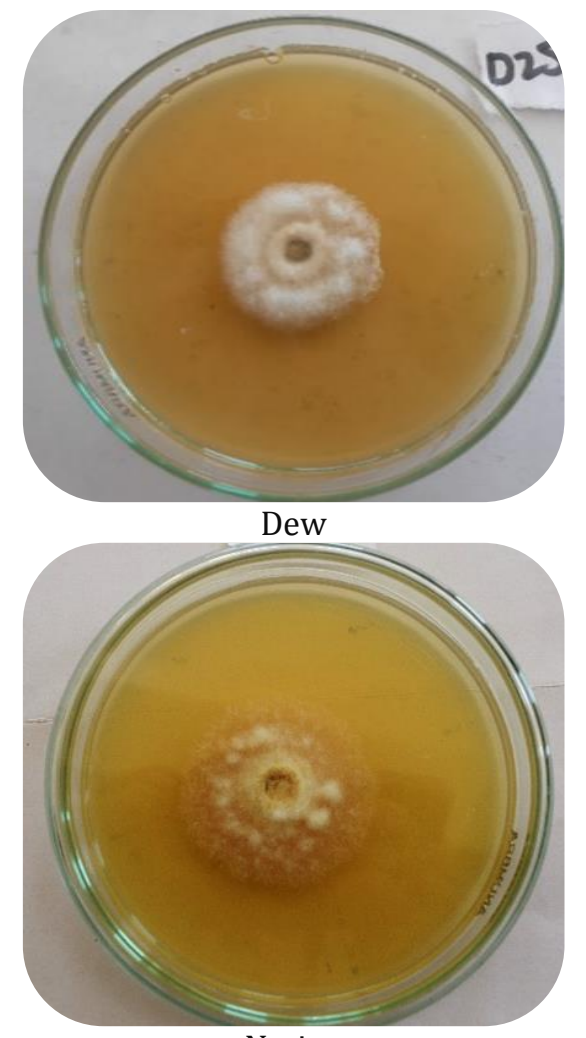

Nativo

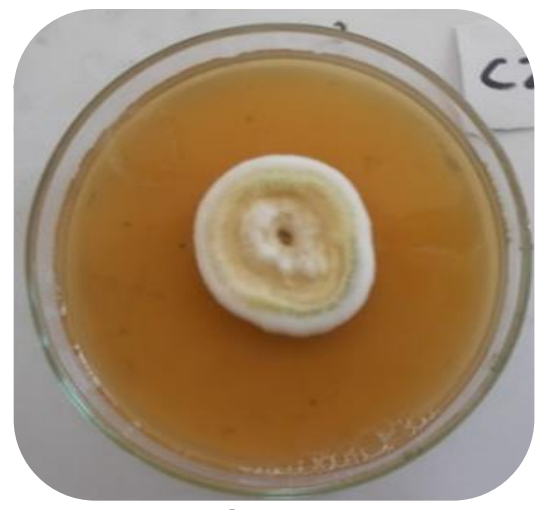

Cabrio Top

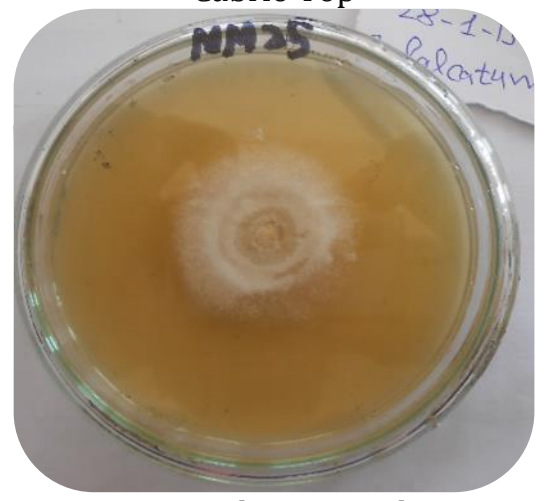

Metaxyl+Mencozeb

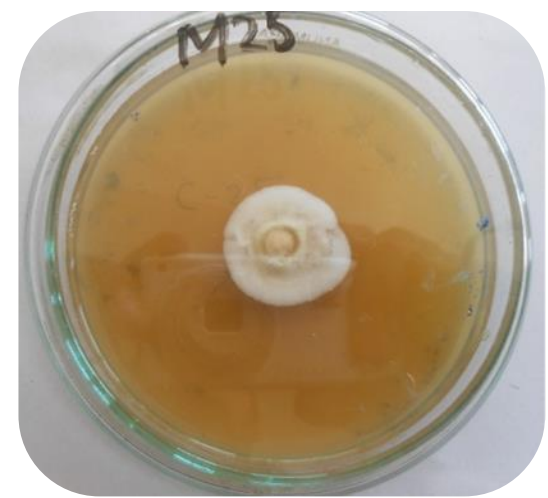

Secex

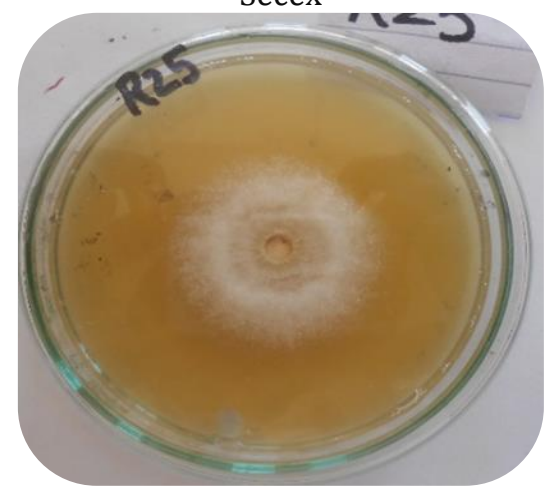

Rally

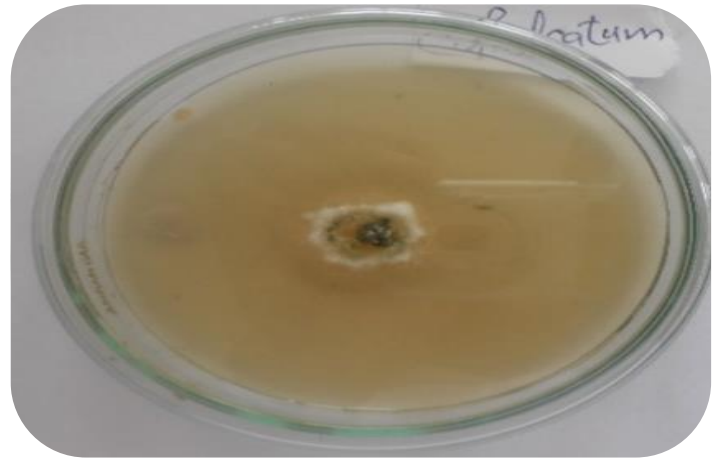

Tilt

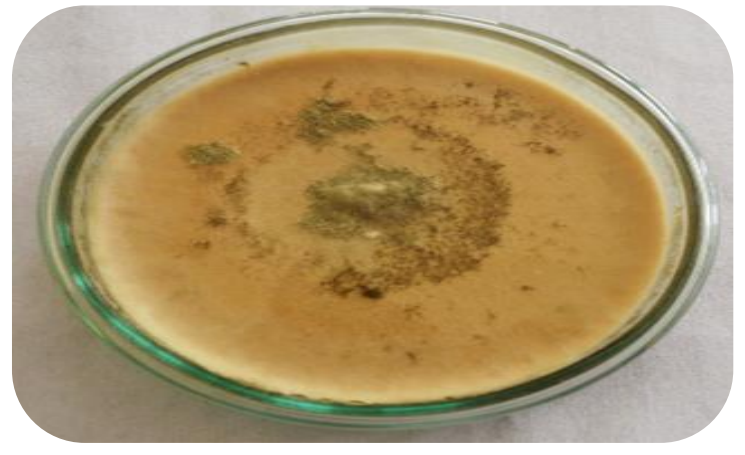

Control

Figure 3. Effect of different fungicides on colony growth of $C$. falcatum at $25 \mathrm{ppm}$ concentration through food poison technique compared with control

\section{DISCUSSION}

Management of red rot through the use of resistant verities is the most reasonable tool but when red rot disease free seed is not accessible, farmers left with no choice other than use of synthetic fungicides (Viswanathan et al., 2009). The effect of seven fungicides were in vitro evaluated for their inhibitory effect on linear growth of $C$. falcatum, causal agent of red rot of sugarcane. Results of tested fungicides indicated that the inhibition percentage was increased by increasing the concentrations of fungicides (Tsakiris et al., 2002; Olanya et al., 2001). Horst,
(2012) reported that fungicides have different kind of action on plants to retard fungal development such as action on unspecific site, on cell membranes, on energy production, on nuclear division, on metabolism of sterol and synthesis of chitin. The mycelial growth of $C$. falcatum showed a different trend in response to different tested fungicides. Among tested fungicides Tilt showed maximum inhibited mycelial growth of C. falcatum. Similar results were found by Bharti et al., (2014) who reported that Tilt most effective fungicide for the management of $C$. falcatum (red rot of sugarcane). 
Contrary to the results of Abbas et al., 2016; Shukla et al., 2013; Imtiaj et al., (2007) who observed that Dithane M45 (Mancozeb) to be the best for percent inhibition colony growth of $C$. falcatum while our findings recorded similar to Shovan et al., 2008; Vijaya et al., 2010 studies that best inhibition was attain with Tilt for all tested concentrations while Mancozeb are almost completely fail to inhabit fungal growth. It may be due to sensitivity of isolates of $C$. falcatum to fungicides application and environmental factors.

Table 4: Mycelium growth (mm) of C. falcatum against different concentrations of fungicides after seven days of inoculation, applied as food poison technique

\begin{tabular}{lllllll}
\hline Fungicides & Time & \multicolumn{5}{c}{ Concentrations } \\
\cline { 3 - 6 } & interval & $10 \mathrm{ppm}$ & $15 \mathrm{ppm}$ & $20 \mathrm{ppm}$ & $25 \mathrm{ppm}$ & Control \\
\hline Cabrio Top & $72 \mathrm{~h}$ & $45.83 \pm 0.76 \mathrm{a}$ & $36.33 \pm 1.15 \mathrm{~b}$ & $32.34 \pm 0.57 \mathrm{~b}$ & $30 \pm 1 \mathrm{a}$ & $55.66 \pm 2.08 \mathrm{a}$ \\
& $12 \mathrm{~h}$ & $59.67 \pm 0.57 \mathrm{ab}$ & $53.17 \pm 0.76 \mathrm{~b}$ & $48.16 \pm 1.04 \mathrm{~b}$ & $42.67 \pm 1.15 \mathrm{a}$ & $67.67 \pm 0.57 \mathrm{a}$ \\
& $168 \mathrm{~h}$ & $66.83 \pm 1.04 \mathrm{c}$ & $62.83 \pm 0.76 \mathrm{c}$ & $57.33 \pm 2.51 \mathrm{~b}$ & $51.67 \pm 1.04 \mathrm{~b}$ & $89.33 \pm 1.15 \mathrm{a}$ \\
\hline Dew & $72 \mathrm{~h}$ & $35.67 \pm 0.57 \mathrm{~b}$ & $28.17 \pm 1.25 \mathrm{c}$ & $22.67 \pm 0.28 \mathrm{c}$ & $18.5 \pm 0.86 \mathrm{c}$ & $55.33 \pm 0.57 \mathrm{a}$ \\
& $12 \mathrm{~h}$ & $46.83 \pm 0.28 \mathrm{c}$ & $39.33 \pm 0.57 \mathrm{c}$ & $31.67 \pm 1.52 \mathrm{c}$ & $25.5 \pm 0.50 \mathrm{c}$ & $65.66 \pm 2.08 \mathrm{a}$ \\
& $168 \mathrm{~h}$ & $54.33 \pm 1.15 \mathrm{~d}$ & $46.83 \pm 0.76 \mathrm{~d}$ & $37.17 \pm 0.28 \mathrm{c}$ & $31.83 \pm 0.76 \mathrm{~d}$ & $88.33 \pm 2.08 \mathrm{a}$ \\
\hline Secex & $72 \mathrm{~h}$ & $28.16 \pm 1.04 \mathrm{c}$ & $24.33 \pm 0.57 \mathrm{~d}$ & $21.17 \pm 0.76 \mathrm{c}$ & $15.67 \pm 0.57 \mathrm{~d}$ & $54.67 \pm 0.57 \mathrm{a}$ \\
& $120 \mathrm{~h}$ & $42.33 \pm 0.57 \mathrm{~d}$ & $33.67 \pm 1.52 \mathrm{~d}$ & $28.5 \pm 1.32 \mathrm{~d}$ & $22 \pm 1 \mathrm{~d}$ & $66.6 \pm 1.15 \mathrm{a}$ \\
& $168 \mathrm{~h}$ & $49.33 \pm 0.57 \mathrm{e}$ & $42.5 \pm 0.50 \mathrm{e}$ & $35.34 \pm 1.52 \mathrm{c}$ & $26 \pm 1 \mathrm{e}$ & $90 \pm 0.00 \mathrm{a}$ \\
\hline Metaxyl+ & $72 \mathrm{~h}$ & $47.33 \pm 1.15 \mathrm{a}$ & $41.00 \pm 0.00 \mathrm{a}$ & $35.83 \pm 0.29 \mathrm{a}$ & $30 \pm 1 \mathrm{a}$ & $55.33 \pm 1.15 \mathrm{a}$ \\
Mencozeb & $120 \mathrm{~h}$ & $61.67 \pm 0.57 \mathrm{a}$ & $58.67 \pm 0.57 \mathrm{a}$ & $52.33 \pm 0.57 \mathrm{a}$ & $43.00 \pm 1 \mathrm{a}$ & $65.66 \pm 0.57 \mathrm{a}$ \\
& $168 \mathrm{~h}$ & $83 \pm 1 \mathrm{a}$ & $77.67 \pm 0.57 \mathrm{a}$ & $69.67 \pm 0.57 \mathrm{a}$ & $59.67 \pm 1.52 \mathrm{a}$ & $89.67 \pm 0.57 \mathrm{a}$ \\
\hline Nativo & $72 \mathrm{~h}$ & $25.33 \pm 0.57 \mathrm{~d}$ & $19.67 \pm 0.28 \mathrm{e}$ & $16.17 \pm 0.28 \mathrm{~d}$ & $12 \pm 1 \mathrm{e}$ & $55.67 \pm 0.57 \mathrm{a}$ \\
& $120 \mathrm{~h}$ & $35.67 \pm 1.52 \mathrm{e}$ & $30.67 \pm 1.52 \mathrm{e}$ & $25.17 \pm 0.28 \mathrm{e}$ & $19.33 \pm 0.57 \mathrm{e}$ & $66 \pm 1 \mathrm{a}$ \\
& $168 \mathrm{~h}$ & $44.67 \pm 0.57 \mathrm{f}$ & $37.63 \pm 0.55 \mathrm{f}$ & $31.67 \pm 0.57 \mathrm{~d}$ & $22.33 \pm 0.57 \mathrm{f}$ & $89.34 \pm 1.15 \mathrm{a}$ \\
\hline Rally & $72 \mathrm{~h}$ & $47.50 \pm 0.86 \mathrm{a}$ & $39.33 \pm 0.57 \mathrm{a}$ & $31 \pm 1 \mathrm{~b}$ & $24.50 \pm 0.50 \mathrm{~b}$ & $55 \pm 1 \mathrm{a}$ \\
& $120 \mathrm{~h}$ & $58.67 \pm 1.52 \mathrm{~b}$ & $51.00 \pm 1 \mathrm{~b}$ & $46.00 \pm 1 \mathrm{~b}$ & $35.33 \pm 0.57 \mathrm{~b}$ & $65.33 \pm 0.57 \mathrm{a}$ \\
& $168 \mathrm{~h}$ & $80.4 \pm 0.52 \mathrm{~b}$ & $74.53 \pm 0.50 \mathrm{~b}$ & $57.67 \pm 0.57 \mathrm{~b}$ & $41.67 \pm 0.57 \mathrm{c}$ & $89 \pm 1 \mathrm{a}$ \\
\hline Tilt & $72 \mathrm{~h}$ & $20.87 \pm 0.23 \mathrm{e}$ & $16.90 \pm 0.36 \mathrm{f}$ & $12.8 \pm 0.72 \mathrm{e}$ & $10.5 \pm 0.50 \mathrm{e}$ & $56 \pm 1.7 \mathrm{a}$ \\
& $120 \mathrm{~h}$ & $31.34 \pm 0.57 \mathrm{f}$ & $23.67 \pm 0.57 \mathrm{f}$ & $17.83 \pm 1.04 \mathrm{f}$ & $15.33 \pm 0.57 \mathrm{f}$ & $67 \pm 1 \mathrm{a}$ \\
& $168 \mathrm{~h}$ & $37.93 \pm 0.90 \mathrm{~g}$ & $29.33 \pm 0.57 \mathrm{~g}$ & $21.57 \pm 0.51 \mathrm{e}$ & $16.5 \pm 050 \mathrm{~g}$ & $89 \pm 1.73 \mathrm{a}$ \\
\hline
\end{tabular}

Our results are to some extent also coordinated with the results obtained by Subhani et al., (2008) who reported that C. falcatum inhibition (100\%) was also found in case of Tilt at different concentrations. Similarly, Bhardwaj and Sahu, (2014) reported that Carbendazim was found to be most effective against $C$. falcatum followed by Folicur, Contaff and Tilt at different concentrations respectively. In the present study, it was found that all the chemicals worked in dose dependent manner (showed maximum inhibition activity at highest concentration).

Constant dependence on fungicides has proven incompatible leading towards severe environmental problems. Screening of sugarcane varieties against red rot of sugarcane helped to evade such problems because it is environmentally sound and appropriate approach to minimize the use of chemicals. Among ten varieties used, two varieties such as NSG-59 and SPF-244 scored 2 on disease rating scale and proved to be resistant on the attack of $C$. falcatum causing red rot of Sugarcane disease. These above-mentioned results are in accordance with those of Singh and Waraitch, (1977) and Gill and Saleem, (1983 a; b) who reported that eight varieties/lines were susceptible, one moderately resistant and four were resistant to red rot disease of sugarcane. These results are in conformity with those of Gupta et al., (1982) who found four varieties/lines resistant and three susceptible to red rot disease. This differential behavior may be attributed to pathogenic variability among $C$. falcatum isolates. The development of new strains in the pathogen due to environmental changes is possible which is not allowing complete resistance in all verities which is already observed by Chona (1980). Our Study also indicated that resistance in sugarcane may be polygenic which is controlled by many genes (Khokhar et al., 2002).

\section{CONCLUSION}

Conclusively, it is urged that fungicide application is one of a sharp tool against disease control in plants if use in integrated manner. Results in present study showed that by increasing concentration of fungicides more fungal inhibition can be achieved. Fungicides can inhabit $C$. 
falcatum efficiently and can be used for treatment of red rot disease of sugarcane. Regular use of fungicides is neither economical nor valuable for the surroundings. On the other hand, varieties don't show significant resistance to red rot disease. Long period of time is required for development of new varieties, because with the emergence of new virulent pathotypes resistance may breaks down and it will become susceptible with the passage of time. That's why; other way of controlling disease such as use of synthetic fungicides for activation of plant defense system can be used.

\section{REFERENCES}

Abbas, H.T., S. T. Sahi, A. Habib and S. Ahmed. 2016. Laboratory evaluation of fungicides and plant extracts against different strains of Colletotrichum falcatum the cause of red rot of sugarcane. Pak. J. Agri. Sci.53:181-186.

Agnihotri, V. P. 1996. Current Sugarcane Disease Scenario and Management Strategies. Indian Phytopathol. 49: 109-126.

Ahmed, M., R. Ali and S. Fasihi. 1986. Effect of different infection level of red rot of sugarcane on cane weight and juice quality. J. Agric. Res. 24: 129-131.

Butler, E. J. 1906. Fungus Diseases of Sugar-cane in Bengal, by EJ Butler, Agricultural Research Institute.

Benicio, V., E. Araujo,F. M. D.Souto, M.J. Benicio and D. C. Felismino. 2003. Identification and cultural characteristics of Aspergillus species isolated in common bean seeds from Paraíba State, Brazil. Fitopatol.Bras. 28:180-183.

Bhardwaj, N. and R. K. Sahu. 2014. Evaluation of some fungicides, botanicals and essential oils against the fungus Colletotrichum falcatum causing red rot of sugarcane. The Bioscan. 9: 175-178.

Bharti, Y. P., B. K. Singh, A. Kumar, S. P. Singh andD. N. Shukla. 2014. Efficacy of fungicides and antibiotics against spore germination and sporulation of Colletotrichum falcatum went; causing red rot disease of sugarcane in-vitro and in-vivo condition. Agriways. 2: 100-105.

Bharti, Y.P., S.K. Vishwakarma, A. Kumar, A. Singh, M.L. Sharma and D.N. Shukla. 2012. Physiological and pathological aspects of some new isolates of Colletotrichum falcatum causing red rot disease in Saccharum spp. complex. Acta Phytopathol. Entomol. Hung. 47: 35-50.

Choi, Yuen-Wah., D. Kevin, Hyde and W.H. Ho. 1999.Single spore isolation of fungi. Fungal Divers.3:29-38
Chona, B. L. 1980. Red rot of sugarcane and sugar industry-a review. Indian Phytopathol.33: 191-207.

Fisher, R. A. 1948. Statistical Methods for Research Workers.Oliver and Boyd, London, UK. 354 pp

Gill, M.A. and A. Saleem. 1983a. Methods of inoculations for the screening of sugarcane varieties against red rot (Colletotrichum falcatum Went). J. Agric. Res. 21:163-166.

Gill, M.A. and A. Saleem.1983b. Screening of genetic stock of sugarcane against red rot disease.Pak J. Bot. 15:117119.

Gupta, M. R., R. Kumar and R.S. Solanki. 1982. Screening of sugarcane varieties against red rot disease. Indi. Sugar J. 8:745-748.

Hansen, H. N. 1926. A simple method of obtaining single spore cultures. Science, 64:384-389.

Hussnain, Z., S. Afghan. 2006. Impact of major cane diseases on sugarcane yield and sugar recovery. Ann. Rep. Shakarganj Sugar Res. Institute, Jhang.

Horst, L. 2012. Mechanism of action of fungicides.Plant Disease. 239.

Hutson, D. and J. Miyamoto. 1998. Fungicidal activity: chemical and biological approaches to plant protection. Oxford University Press.

Imtiaj, A., M. S. Alam, Islam, A. K. M. R. Alam and T. S. Lee. 2007. In vitro studies on Colletotrichum falcatum the causal of red rot disease of sugarcane. AmericanEurasian J. Agric. Environ. Sci. 2: 511-517.

Khan, A., M. Awais, W. Raza and A. Zia. 2011. Identification of sugarcane lines with resistance to red rot. Pak. J. Phytopathol. 23: 98-102.

Khokhar, L.K., F. Sohail and M.A. Qureshi. 2002. Evaluation of sugarcane cultivars for resistance to Colletotrichum falcatum Went. Pak. J. Agric. Res. 18: 31-33.

Kinkema, M., R.J. Geijskes, K. Shand, H.D. Coleman, P.C. De Lucca, A. Palupe, M.D. Harrison, I. Jepson, J.L. Dale and M.B. Sainz. 2014. An improved chemically inducible gene switch that functions in the monocotyledonous plant sugar cane. Plant Mol. Biol. 84: 443-454

Kumar, T., M.R. Khan, S.A. Jan, N. Ahmad, N. Niaz Ali, M.A. Zia, S. Roomi, A. Iqbal and G.M. Ali. 2014. Efficient regeneration and genetic transformation of sugarcane with AVP1 gene. Am Eurasian J Agric Environ Sci.14: 165-171.

Malathi, P., R.Viswanathan, P. Padmanaban, D. Mohanraj, V.G. Kumar and K.P. Salin. 2008. Differential accumulation of 3-deoxy anthocyanidin phytoalexins 
in sugarcane varieties varying in red rot resistance in response to Colletotrichum falcatum infection. Sugar Tech. 10: 154-157.

Olanya, O. M., E. Adipala,J.J. Hakiza, J.C.Kedera, P. Ojiambo, J.M. Mukalazi and R. Nelson. 2001. Epidemiology and population dynamics of Phytophthora infestans in Sub-Saharan Africa: progress and constraints. African Crop Sci. J.9: 185-193.

Rao, G.P., S. Srivastava, P.S.Gupta, S.R.Sharma, A.Singh, S. Singh and C. Marcone. 2008. Detection of sugarcane grassy shoot phytoplasma infecting sugarcane in India and its phylogenetic relationships to closely related phytoplasmas. Sugar Tech. 10: 74-80.

Sengar, A. S., K.S. Thind, B.Kumar, M. Pallviand S.S. Gosal. 2009. In vitro selection at cellular level for red rot resistance in sugarcane (Saccharumspp.). Plant growth Regul.58:201-209.

Shahina, F. and K. Firoza. 2007. Nematodes and pest problems in sugarcane. Pak. Sug. J. 22: 18-28.

Sharvelle, E. G. 1961. The nature and uses of modern fungicides.1:1-308.

Shovan, L.R., M.K.A. Bhuiyan, J.A.Begum and Z. Pervez. 2008. In vitro control of Colletotrichum dematium causing anthracnose of soybean by fungicides, plant extracts and Trichoderma harzianum .Int. J. Sustain. Crop Prod. 3:10-17.

Shukla, R. S., A. Khaliq and M. Alam. 2013. Chemical control of blossom blight disease of sarpagandha caused by Colletotrichum capsici. Afr. J. Biotechnol. 9: 63976400.

Singh, K. and Singh. 1989. Red Rot, In: Sugarcane Diseases Major Diseases (Eds., C. Ricaud, B.T. Egan, A.G. Gillaspie, C.G. Hughes). Elsevier, Amsterdam. 169188.

Singh, O. X. and K. S. Waraitch. 1977. Metabolic changes induced by Colletotrichum falcatum Went. in sugarcane. Sugarcane Pathologist News Letter. 19:7-9.

Subhani, M.N., S.T. Sahi, S. Hussain, A. Ali, J. Iqbal and K. Hameed. 2011. Evaluation of various fungicides for the control of gram wilt caused by Fusarium oxysporum f. sp. ciceris. Afr. J. Agric. Res. 6: 45554559.

Subhani, M.N., M.A. Chaudhry, A. Khaliq and F. Muhammad. 2008. Efficacy of various fungicides against sugarcane red rot (Colletotrichum falcatum). Int. J. Agric. Biol. 10: 725-727.

Tsakiris, E., D.I. Karafyllidis and J. Mansfield. 2002. Management of potato late blight by fungicides. ActaHortic. 579: 567-570.

Vijaya, H.K., S. Kulkarni and Y.R.Hegde. 2010. Chemical control of sett rot of sugarcane caused by Ceratocystis paradoxa. Karnataka J. Agric. Sci. 1-20.

Viswanathan, R., R.Nandakumar, R. Samiyappan. 2003. Involvement of pathogenesis-related proteins in Pseudomonas spp. induced systemic resistance against Colletotrichum falcatum in sugarcane. J. Plant Dis. Prot. 110: 524-537.

Viswanathan, R. and R. Samiyappan. 2002. Induced systemic resistance by fluorescent pseudomonads against red rot disease of sugarcane caused by Colletotrichum falcatum. Crop Prot. 21: 1-10.

Viswanathan, R. and G.P. Rao. 2011. Disease scenario and management of major sugarcane diseases in India. Sugar Tech.13: 336-353.

Viswanathan, R., A.R.Sundar, P. Malathi, P.R. Rahul, V.G. Kumar, R. Banumathy, P.T.Prathima, M. Raveendran, K.K. Kumar and P. Balasubramanian. 2009. Interaction between sugarcane and Colletotrichum falcatum causing red rot: Understanding disease resistance at transcription level. Sugar Tech. 11: 4550.

Viswanathan, R., D. Mohanraj, P. Padmanaban and K.C. Alexander. 1996. Synthesis of phytoalexins in sugarcane in response to infection by Colletotrichum falcatum Went. Acta. Phytopatol.Entomol. Hung. 31: 229-237.

Zamir, R., S.A. Khalil, S.T. Shah, M.S. Khan, K. Ahmad, Shahenshah and N. Ahmad. 2012. Efficient in vitro regeneration of sugarcane (Saccharum officinarum L.) from bud explants. Biotechnol.Biotechnol. Equip. 26: 3094-3099. 